DOI: https://doi.org/10.32839/2304-5809/2021-3-91-72

УДК 336.77

Блащук-Дев’яткіна Н.З., Себестянович I.C.

Львівський національний університет імені Івана Франка

\title{
КРЕДИТУВАННЯ МАЛОГО ТА СЕРЕДНЬОГО БІЗНЕСУ НА СУЧАСНОМУ ЕТАПІ РОЗВИТКУ ЕКОНОМІКИ УКРАЇНИ
}

\begin{abstract}
Анотація. У статті розглянуто сучасний стан малого та середнього бізнесу, особливості його кредитування. Проаналізовано основні показники структурної статистики по суб’ектах господарювання. Продемонстровано рейтинг банківських послуг на вітчизняному ринку в контексті підтримки розвитку МСБ. Розглянуто заходи стимулювання малого та середнього бізнесу зі сторони НБУ. Охарактеризована програма «Доступні кредити 5-7-9\%». Подано висновки щодо ролі малого та середнього бізнесу в економіщі країни та шляхи його подальшого розвитку.
\end{abstract}

Ключові слова: малий та середній бізнес, кредитування, джерела фінансування, банківське кредитування, умови кредитування.

Blashchuk-Devyatkina Nataliya, Sebestyanovych Iryna Lviv National University of Ivan Franko

\section{LENDING TO SMALL AND MEDIUM BUSINESS AT THE CURRENT STAGE OF UKRAINIAN ECONOMY DEVELOPMENT}

Summary. In the article are considered the current state of small and medium business and features of its crediting. The main indicators of structural statistics by economic entities are analyzed. The rating of banking services in the domestic market in the context of supporting the development of SMB(small and medium business) is demonstrated. Measures to stimulate small and medium businesses by the NBU(National Bank of Ukraine) are considered. The program "Available loans 5-7-9\%" is characterized. Conclusions are given on the role of small and medium business in the country's economy and ways of its further development. The program of further development is characterized. Small and medium businesses play an important socio-economic role in the functioning of the country's economic system, especially at the rate of recovery from the crisis. Therefore, support is an important task for the country. One of the main obstacles to the development of SMB is the lack of its own financial resources, which exacerbates its need for borrowed resources, especially in bank loans. The acute need of SMB for bank lending, on the one hand, and the difficulties of banks to meet it due to high risk and small loans, on the other hand, determine the need for scientific research to resolve this contradiction to intensify SMB bank lending. Given the unstable economic situation in Ukraine, small and medium businesses need significant support from the authorities. It is necessary to regulate refinancing rates and minimize the cost of loans from the NBU (National Bank of Ukraine) in order to reduce the cost of bank loans. It is important to look for alternative ways to secure loans, namely to ensure financial risks and create guarantee funds, to provide state guarantees. Banks need to implement more innovative projects, develop new banking products for small businesses and master new credit technologies. As for enterprises, they should increase their trust in banks, demonstrate information about their activities truthfully and accurately, which will positively affect the decision made by the bank.

Keywords: small and medium businesses, lending, sources of financing, bank lending, lending conditions.

$\Pi^{2}$ остановка проблеми. На сучасному етапі розвитку вітчизняної економіки однією із найважливіших проблем є занепад малого та середнього бізнесу (МСБ), який відіграє важливу роль соціального та економічного розвитку. Основною перешкодою, яка постає на шляху розвитку МСБ є обмеженість власних фінансових ресурсів, що призводить до домінування банківського кредиту. Найбільш характерною дана ситуація $є$ для України, оскільки вітчизняні суб'єкти господарювання мають доступ лише до банківського кредиту. Крім того, кризові умови значно скоротили кредитування малого та середнього бізнесу, що ускладнило подолання економічної кризи.

Аналіз останніх досліджень і публікацій. Проблеми вивчення розвитку малого та середнього бізнесу, а зокрема його кредитування, були відображені в працях таких вітчизняних дослідників як А. Кисельова, О. Кружеля, О. Сич, А. Чухна, Б. Варналія, А. Мельника та ін. Саме вони дослідили питання, що стосуються креди- тування малого та середнього підприємництва та запропонували способи їх вирішення.

Виділення не вирішених раніше частин загальної проблеми. При врахуванні надбань науковців по даній тематиці, можна зробити висновок, що сучасний стан фрінансування МСБ потребуе подальшого дослідження, особливо в сучасних політичних умовах.

Мета статті. Головною метою цієї роботи $\epsilon$ проведення аналізу сучасного стану та умов кредитування малого та середнього бізнесу, обгрунтуванні заходів щодо вирішення проблем у сорері фінансування МСБ.

Виклад основного матеріалу. Кредитування вважається однією із найважливіших етапів малого та середнього бізнесу України, оскільки дає можливість підприемствам бути конкурентоспроможними. Більша половина економічно та інноваційно активного населення України зосереджено саме у даному секторі економіки.

Умови залучення банківських кредитів, які вважаються одним із основних джерел зовніш- 
нього фінансування МСБ, залишаються жорсткими, а сам процес кредитування проблемним, часозатратним та високоризикованим. Проте, малий та середній бізнес досить залежний від традищійного банківського кредитування через нерозвиненість інвестиційного ринку та відповідної інституційної підтримки МСБ.

Малий та середній бізнес в Україні приносить $55 \%$ ВВП в економіку країни, в тому числі частка малого бізнесу становить 16\% ВВП [1].

За даними Державної служби статистики України, у структурі підприемництва нашої країни за розміром підприемств станом на кінець 2019 року частка малих підприемств становила 362328 одиниць, тобто 95\%, середніх 17751 (4,9\%), великих - 518 (0,1\%) (рис. 1).

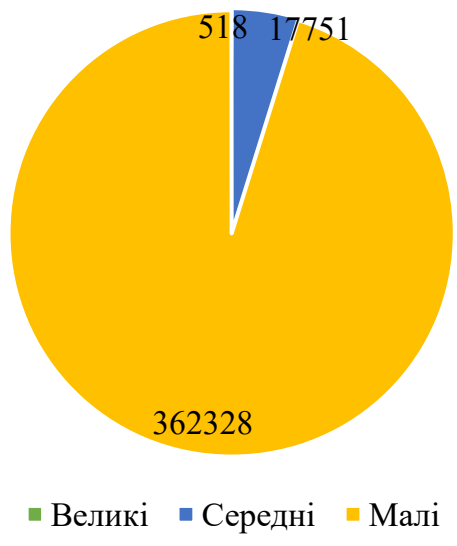

Рис. 1. Кількість підприемств

за їхіми розмірами у відсотках до загальної кількості підприемств станом на 2019 p.

Джерело: розроблено авторали за даними [2]

Для того, аби дослідити динаміку розвитку підприємництва (а саме МСБ), проаналізуємо основні показники структурної статистики по суб'єктах господарювання протягом 2015-2019 рр. (табл. 1).

За показниками табл. 1 можна констатувати ï негативну тенденцію до 2016 року. Так, кількість малих підприемств збільшилась у 2019 році на 71174 од. (в 2016 р. їх кількість становила 291154, в 2019 р. - 362328), середніх - на 2919 од.

Відповідно до показника абсолютної зміни, можна спостерігати за збільшенням підприемств у 2019 році, порівняно з 2015 р. щодо середніх підприемств, то цей показник становить 1,2 ; для малих $-1,1$.

Проаналізуемо рейтинг банківських послуг на вітчизняному ринку в контексті підтримки розвитку МСБ (табл. 2).

Аналізуючи дані табл. 2 можна підсумувати, що найменші ставки пропонують такі банки як Кредобанк (8,86\%), Ощадбанк $(12,25 \%)$, АльфаБанк Україна (12,20\%), Credit Agricole (12,5\%) та Укргазбанк (12,6-13,1\%). Зазначимо, що відсотки по кредитах в Україні є досить високі на відміну від розвинених країн, де ставки коливаються від $0,1 \%$ до 4\% річних (наприклад, в Японії-0,1\%, Канада - 2\%, США- 2,75\%).

На сьогоднішній день Нацбанк фокусуеться на тому, щоб прозорий бізнес міг легко та без перешкод отримувати кредитування та інвестищіі. Тому позитивним трендом у кредитуванні в 2020 році стало зниження до однознакових позначок ставок за короткостроковими бізнес-кредитами якісним позичальникам. Це відбулося завдяки низькій та стабільній індрлящї, а також стимулюючій монетарній політиці НБУ та суттєвому зниженню депозитних ставок. У майбутньому це також дозволить підтримувати низькі ставки за кредитами [4].

Минулого року бізнес відчув на собі наслідки коронакризи, це окремо стосувалося і малих та середніх підприемств. Тому відбувалось спонукання банків здійснювати своєчасні реструктуризації позичальників, які постраждали під

Таблиця 1

Показники структурної статистики по суб’ектах господарювання з розподілом за їх розмірами

\begin{tabular}{|c|c|c|c|c|c|}
\hline \multirow{2}{*}{$\begin{array}{c}\text { Кількість } \\
\text { суб'єктів } \\
\text { господарювання, } \\
\text { од. }\end{array}$} & \multirow[b]{2}{*}{ Усього } & \multicolumn{3}{|c|}{ Підприемства } & \multirow{2}{*}{$\begin{array}{c}\text { ФОП } \\
\text { Усього }\end{array}$} \\
\hline & & великі & середні & малі & \\
\hline 2015 & 1974318 & 423 & 15203 & 327814 & 1630878 \\
\hline 2016 & 1865530 & 383 & 14832 & 291154 & 1559161 \\
\hline 2017 & 1805059 & 399 & 14937 & 322920 & 1466803 \\
\hline 2018 & 1839593 & 446 & 16057 & 339374 & 1483716 \\
\hline 2019 & 1941625 & 518 & 17751 & 362328 & 1561028 \\
\hline $\begin{array}{c}\text { Абсолютна зміна, } \\
\text { 2019/2015 рр. }\end{array}$ & 1 & 1,2 & 1,2 & 1,1 & 0,9 \\
\hline \multicolumn{6}{|c|}{ Обсяг реалізованої продукції (товарів, послуг), млн грн. } \\
\hline 2015 & 5556540,4 & 2053189,5 & 2168764,8 & 937112,8 & 397473,3 \\
\hline 2016 & 6726739,8 & 2391454,3 & 2668695,7 & 1177385,2 & 489204,6 \\
\hline 2017 & 8312271,9 & 2929516,6 & 3296417,9 & 1482000,7 & 604336,7 \\
\hline 2018 & 9966804,5 & 3515839,5 & 3924059,6 & 1766150,4 & 760755,0 \\
\hline 2019 & 10524112,8 & 3631415,3 & 4168439,4 & 1839875,9 & 884382,2 \\
\hline $\begin{array}{c}\text { Абсолютна зміна, } \\
\text { 2019/2015 рр. }\end{array}$ & 1,9 & 1,8 & 1,9 & 2 & 2,2 \\
\hline
\end{tabular}

Джерело: розроблено авторами за даними [2] 
Таблиця 2

Рейтинг умов кредитування підприемств МСБ банками в Україні

\begin{tabular}{|c|c|c|c|c|}
\hline Банк & $\begin{array}{c}\text { Річна ставка, } \\
\text { \% }\end{array}$ & $\begin{array}{c}\text { Разова комісія за } \\
\text { видачу суми кредиту, \% }\end{array}$ & $\begin{array}{c}\text { Щомісячна } \\
\text { комісія }\end{array}$ & $\begin{array}{c}\text { Перший } \\
\text { внесок, \% }\end{array}$ \\
\hline Кредобанк & 8,86 & 1,0 & - & від 20,0 \\
\hline Ощадбанк & 12,25 & 0,5 & - & від 20,0 \\
\hline Альфа-Банк Україна & 12,20 & 0,9 & - & від 30,0 \\
\hline ПриватБанк & 14,0 & - & - & від 25,0 \\
\hline Стедіt Аягісое & 12,5 & 1,0 & - & від 25,0 \\
\hline Укргазбанк & $12,6-13,1$ & 1,0 & - & від 30,0 \\
\hline Укрексімбанк & 13,30 & - & -10 & від 0,0 \\
\hline Правекс Банк & 15,0 & 0,5 & від 30,0 \\
\hline
\end{tabular}

Джерело: розроблено авторами за даними [3]

час коронакризи, щоб пом'якшити негативний ефрект від карантину [4].

НБУ працював і продовжуе працювати над зниженням рівня непрацюючих кредитів (NPL), які є тягарем для банків та заважають розвивати кредитні продукти, зокрема і для бізнесу. Частка NPL за 2020 рік скоротилася 3 48,4\% до 41\% [4].

Як зауважують в Нацбанку, як наслідок, уже у другій половині 2020 року бізнес-кредитування почало відновлення. А найкращу динаміку показали підприемства МСБ: наприкінці року обсяг чистих кредитів в цьому сегменті щомісяця зростав на $3 \%$ у річному вимірі [4].

Зростанню обсягів кредитів МСБ сприяла i урядова програма «Доступні кредити 5-7-9». Метою цієї програми було: кредит на фінансування інвестиційного проекту МПП; кредит на поповнення обігових коштів, необхідних для реалізації інвестиційного проекту в розмірі до $25 \%$ від його вартості (надаеться виключно у поєднанні 3 інвестиційним кредитом). Результати програми: видано більше 10 тис. позик на загальну суму понад 25 млрд грн. Понад $50 \% 3$ них видані для редінансування попередньо отриманих позик, решту підприємці отримали на капітальні інвестиції та як антикризові кредити, що логічно для кризового періоду [4]. Крім того, програма «Доступні кредити 5-7-9» здійснювала такі антикризові дії:

1. Підтримка інвестиційних проектів, пов'язаних 3 виробництвом лікарських засобів, медичних виробів, медичного обладнання, а також рефінансування кредитів ММП на вказані цілі.

2. Підтримка ліквідності ММП за рахунок кредиту на поповнення обігових коштів без прив'язки до витрат за інвестиційним проектом.

3. Рефінансування існуючої заборгованості за кредитами ММП в банках України шляхом надання нового кредиту та/або зміни умов діючого кредитного договору з метою надання йому державної підтримки, у вигляді компенсації процентів, передбаченої програмою [5].

За оцінками НБУ, покращити результати 2020 року допоможе також затверджений урядом механізм кредитних гарантій на портоельній основі (до 70\% боргу за кожним окремим кредитом та 50\% за портоелем). Банки-кредитори зможуть перекласти частину кредитного ризику позичальника на державу. Адже навіть плато- спроможному малому бізнесу дуже часто бракує достатнього забезпечення. Нові кредитні гарантії заберуть цю перешкоду [4].

Також здійснюеться розширення можливостей для кредитування МСБ. Були спрощені підходи банків до оцінки ризиків за такими кредитами; оцінка невеликих кредитів, які не створюють значних ризиків, здійснюеться за спрощеною процедурою. Зокрема, для малого і середнього бізнесів, ФОПів не встановлюються жодних жорстких вимог. Кожен банк самостійно за власними правилами оцінюе позичальників, що беруть невеликі кредити [4].

Висновки 3 даного дослідження i перспективи. Малий i середній бізнес відіграє важливу соціально-економічну роль у фрункціонуванні економічної системи країни, особливо на етапі їі виходу з кризи. Тому його підтримка $є$ важливим завданням держави. Однією з основних перешкод на шляху розвитку МСБ $е$ нестача власних фрінансових коштів, що загострюе його потребу в запозичених ресурсах, насамперед, у банківських кредитах. Гостра потреба МСБ в банківському кредитуванні, 3 одного боку, та труднощі банків щодо їі задоволення через високу ризикованість та невеликі обсяги кредитів, 3 другого, визначають необхідність наукового пошуку шляхів вирішення даної суперечності для активізації банківського кредитування МСБ.

Враховуючи нестабільну економічну ситуацію в Україні малий та середній бізнес потребуе значної підтримки зі сторони органів влади. Потрібно регулювати ставки рефрінансування та мінімізувати вартість кредитів зі сторони НБУ (Національний Банк України) для того, аби здешевити банківські кредити.

Важливо шукати альтернативні способи для забезпечення кредитів, а саме страхувати фрінансові ризики та створювати гарантійні фони, надавати державні гарантії.

Зі сторони банків потрібно впроваджувати більше інноваційних проектів, розробляти нові банківські продукти саме для малого підприємництва та освоювати нові кредитні технології.

Щодо підприемств, то вони мають збільшувати свою довіру до банків, інформацію своєї діяльності демонструвати правдиво та достовірно, що позитивно вплине на рішення, прийняте банком. 


\section{Список літератури:}

1. Частка малого та середнього бізнесу і BВП України. URL: https://zn.ua/ukr/ECONOMICS/chastka-malogo-iserednogo-biznesu-u-vvp-ukrayini-55-mert-315597_.html

2. Державна служба статистики України. URL: http://www.ukrstat.gov.ua/

3. Рейтинг банківських послуг: «Bankchart». URL: https://bankchart.com.ua/\#

4. НБУ розповів, як стимулюе кредитування малого бізнесу. URL: http://finbalance.com.ua/news/nbu-rozpovivyak-stimulyu-kredituvannya-maloho-biznesu

5. Доступні кредити 5-7-9\%. URL: https://5-7-9.gov.ua/\#prog

\section{References:}

1. Share of small and medium business and GDP of Ukraine. URL: https://zn.ua/ukr/ECONOMICS/chastka-malogoi-serednogo-biznesu-u-vvp-ukrayini-55-mert-315597_.html (accessed 25 March 2021)

2. State Statistics Service of Ukraine. URL: http://www.ukrstat.gov.ua/ (accessed 25 March 2021).

3. Rating of banking services: «Bankchart». URL: https://bankchart.com.ua/\# (accessed 25 March 2021).

4. NBU told how to stimulate lending to small businesses. URL: http://finbalance.com.ua/news/nbu-rozpoviv-yakstimulyu-kredituvannya-maloho-biznesu (accessed 25 March 2021).

5. Available loans 5-7-9\%. URL: https://5-7-9.gov.ua/\#prog (accessed 25 March 2021). 